\title{
Estuarine production of resident and nursery fish species: Conditioning by drought events?
}

\author{
M. Dolbeth ${ }^{\text {a,* }}$, F. Martinho ${ }^{\text {a }}$, I. Viegas ${ }^{\text {a }}$, H. Cabral ${ }^{\text {b }}$, M.A. Pardal ${ }^{\text {a }}$ \\ ${ }^{\mathrm{a}}$ Institute of Marine Research (IMAR), clo Department of Zoology, University of Coimbra, 3004-517 Coimbra, Portugal \\ ${ }^{\mathrm{b}}$ Instituto de Oceanografia, Faculdade de Ciências da Universidade de Lisboa, Campo Grande, 1749-016 Lisboa, Portugal
}

Received 3 August 2007; accepted 19 November 2007

Available online 8 December 2007

\begin{abstract}
The production of resident (Pomatoschistus minutus and Pomatoschistus microps) and marine juvenile fish species using the Mondego estuary (central Portugal) as nursery grounds (Dicentrarchus labrax, Platichthys flesus, Solea solea), was assessed in order to: (1) understand the potential of the estuary for fish production; (2) know the production of nursery fish species likely to be exported to the coastal stocks; and (3) how anthropogenic and natural stress could influence the estimated production. Sampling occurred from June 2003 to May 2006 and together the 5 species in study comprised around $70 \%$ of the whole fish community numbers and biomass. Increasing drought conditions were observed, starting with a normal hydrological year in 2003 until attaining a severe drought in 2005, which resulted in low river discharges $\left(1 / 3\right.$ of the mean river discharges in 2003). Additionally, high water temperatures were observed in 2003 and 2005 (24 and $26{ }^{\circ} \mathrm{C}$, night temperatures). The secondary production was estimated using the increment summation method, after recognition of the cohorts. Production was in general lower in the Mondego estuary when compared to other systems, which was associated to the estuary's small area (only $3.4 \mathrm{~km}^{2}$, less than 1/4 of area compared to other studied systems). Dicentrarchus labrax was among the most productive species. Production decreased in the drought year for all species, especially evident for D. labrax, P. minutus and $P$. flesus. No direct effects could be attributable to the salinity and temperature variations and to the low freshwater discharges (resulting from the drought and high temperatures), yet these were pointed as probable major reasons for the decreased production. A significant reduction $(15-45 \%$ reduction in the estuarine production) was also concluded for the potential production to be exported for coastal areas by the nursery species in the drought conditions.
\end{abstract}

(C) 2007 Elsevier Ltd. All rights reserved.

Keywords: fish production; resident species; nursery species; drought; Mondego estuary

\section{Introduction}

Estuarine systems are extremely valuable for many marine fish species of the continental shelf, by providing important nursery grounds (Cabral et al., 2007; Martinho et al., 2007a; Nicolas et al., 2007), as well as for several other fishes, such as the resident ones, spending their complete life cycle within the estuary (Elliott and Dewailly, 1995; Dolbeth et al., 2007a). Frequently, these two ecological fish guilds (marine juvenile and resident) represent the major part of the fish community found in estuarine systems (Elliott and Dewailly, 1995;

\footnotetext{
* Corresponding author.

E-mail address: mdolbeth@ci.uc.pt (M. Dolbeth).
}

Martinho et al., 2007b). The juvenile growth and survival of the marine species, hence recruitment into adult populations, and the maintenance of the resident species within the estuarine ecosystem are greatly determined by its environmental quality, regarding both anthropogenic stress and natural variability (Nicolas et al., 2007). The availability of essential habitats (such as seagrasses and saltmarshes), providing protection from predators, and their great production, providing abundant food supplies, are considered as major determinants for fishes in estuaries (Beck et al., 2001; Cabral et al., 2007; Martinho et al., 2007a). Several of the marine juvenile fishes that occur in estuaries are commercially important, hence estuaries may be considered as essential ecosystems for the renewal of fisheries resources, acquiring also a direct relevant 
economic value for mankind (Houde and Rutherford, 1993; Cowley and Whitfield, 2002; Able, 2005; Nicolas et al., 2007). Regarding resident species, their role as intermediates in the estuarine food web turns them crucial for the overall dynamics and functioning of the estuarine system (Leitão et al., 2006; Dolbeth et al., 2007a). Yet, estuarine areas are highly affected by human activities such as habitat reclamation, water quality impoverishment and fishing activities (Cabral et al., 2007; Vasconcelos et al., 2007) and are known for their high natural environmental variability (Maes et al., 2004; Elliott and Quintino, 2007). In this perspective, understanding the potential of estuarine areas for these fishes production and the influence of external environmental or anthropogenic impacts on that production becomes quite relevant. This information may be useful as a tool to support protection measures and ensure resource sustainability, or for the study of the overall estuarine ecological integrity. In fact, production estimates integrate the influence of numerous biotic variables and environmental conditions affecting individual growth and population mortality (Cusson and Bourget, 2005; Dolbeth et al., 2005). Therefore, production studies have been used to assess the impacts of natural and anthropogenic stressors (Cardoso et al., 2005; Dolbeth et al., 2005, 2007b), in ecosystem modelling studies (energy budgets and flows, Gamito and Erzini, 2005; Patrício and Marques, 2006), and for fish assemblages have been used more frequently to assess the potential yields for fishery species (Houde and Rutherford, 1993; Wilson, 2002; Pombo et al., 2007).

The present study aims to estimate the secondary production of the resident and marine juvenile fish species of the Mondego estuary (central Portugal). More specifically, it aims to understand: (1) the productive potential of the estuary for the fish resources, and ultimately for other consumers; (2) the production potential to be exported by the marine juveniles to the coastal stocks (infer on the production produced in the estuary transferred to the coastal areas); and (3) how anthropogenic and natural stress influence the production estimates.

\section{Material and methods}

\subsection{Study site}

The Mondego estuary (Portugal) is located in a warm temperate region, on the Atlantic coast of Portugal $\left(40^{\circ} 08^{\prime} \mathrm{N}\right.$, $\left.8^{\circ} 50^{\prime} \mathrm{W}\right)$ (Fig. 1). It is a small estuary $\left(3.4 \mathrm{~km}^{2}\right.$ area), with two arms (north and south) of distinct hydrologic characteristics. The north arm is deeper (4-10 $\mathrm{m}$ during high tide, tidal range $1-3 \mathrm{~m}$ ), it is a main navigation channel and is the location of the Figueira da Foz harbour. Besides the severe changes imposed by the construction of harbour facilities, constant dredging and shipping occurs in this area, causing physical disturbance of the bottom. The main freshwater input to the north arm is from the Mondego river. The south arm is shallower (2-4 $\mathrm{m}$ during high tide, tidal range $1-3 \mathrm{~m}$ ), characterized by large areas of exposed intertidal flats during low tide (about $75 \%$ of total area). Water circulation in the south arm mostly depends on the tides and on the freshwater input

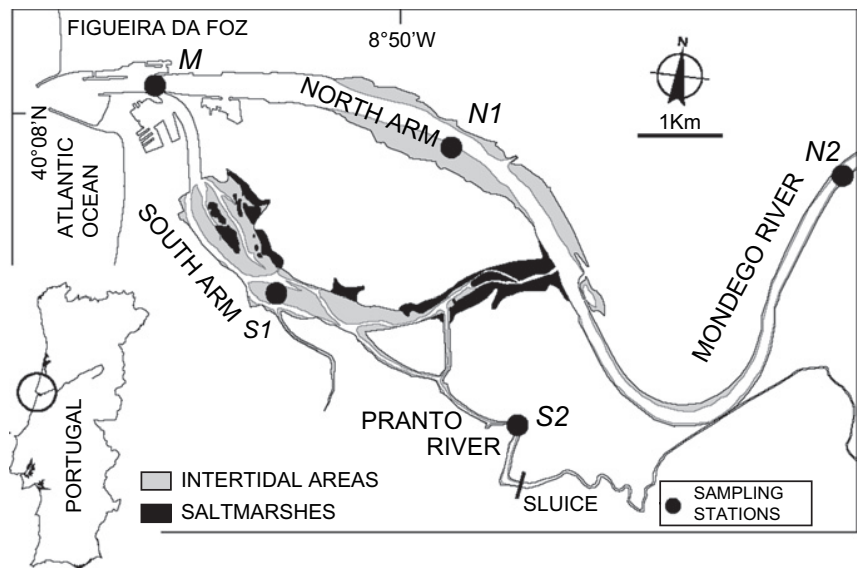

Fig. 1. The Mondego estuary, with indication of the sampling stations, intertidal area and saltmarshes.

from the Pranto river (Fig. 1), as the upstream areas are almost silted up, with only a small connection with north arm. The Pranto river is controlled by a sluice according to the water needs in the rice fields of Mondego valley. The downstream areas of the south arm are relatively unchanged, with Spartina maritima marshes and a Zostera noltii meadow, but in the inner parts the seagrass community has completely disappeared, mainly due to severe eutrophication problems occurring in the past (Lillebø et al., 2005; Dolbeth et al., 2007b). In 1998/1999 mitigation measures were taken to reduce the nutrient loading and the system seems to be gradually recovering (for further details see Cardoso et al., 2005; Dolbeth et al., 2007b).

\subsection{Sampling procedures}

From June 2003 to May 2006 fish were collected monthly, using a $2 \mathrm{~m}$ beam trawl, with one tickler chain and $5 \mathrm{~mm}$ stretched mesh size in the cod end. Sampling was carried out during the night, at the ebbing tide of spring tides, at five stations (M, S1, S2, N1, N2, Fig. 1): M - at $1.5 \mathrm{~km}$ from the estuary's mouth, $8.7 \pm 1.2 \mathrm{~m}$ deep, area subjected to constant dredging; S1 - located upstream a Zostera noltii bed, $2.3 \pm 0.4 \mathrm{~m}$ deep; S2 - near the Pranto river sluices, which controls the main freshwater flow from Pranto river to the south arm, $2.4 \pm 1.0 \mathrm{~m}$ deep; $\mathrm{N} 1$ - with regular freshwater flow, $5.5 \pm 0.5 \mathrm{~m}$ deep; $\mathrm{N} 2$ - most upstream area, with lower saline influence and permanent freshwater flow from the Mondego river, $4.5 \pm 0.3 \mathrm{~m}$ deep. Each survey consisted of three hauls, at each sampling station, in a total of 1015 min duration per station. All fish caught were identified, measured (total length, with $1 \mathrm{~mm}$ precision) and weighted (wet weight $-\mathrm{WW}$, with $0.001 \mathrm{~g}$ precision). A detailed description of the community structure is provided in Martinho et al. (2007b). Due to the amount of data required for the production estimates, only the most abundant fish species, along the surveyed period, were used in the present study, i.e. the marine juveniles using the estuary as nursery grounds - nursery species, Dicentrarchus labrax, Platichthys flesus, Solea solea and the residents Pomatoschistus minutus and 
Pomatoschistus microps, which live in the estuary throughout their life cycle (nursery and resident ecological guilds, adapted from Elliott and Dewailly, 1995, and according to Martinho et al., 2007b).

In each sampling station, water transparency and depth were registered, and dissolved oxygen, temperature, $\mathrm{pH}$ and salinity were measured from the water collected near the bottom. Precipitation values were acquired in the Casal do Rato 13D/04UG station, from INAG - Portuguese Water Institute (available in http://www.snirh.inag.pt). Freshwater runoff was acquired from INAG station Açude Ponte Coimbra 12G/ 01A, near the city of Coimbra (located $40 \mathrm{~km}$ upstream).

\subsection{Secondary production}

The population structure of each species was defined by tracking recognizable cohorts from the successive sampling dates. Spatial samples were pooled together and analyzed through size frequency distribution of successive sampling dates. For Dicentrarchus labrax, Platichthys flesus and Solea solea the cohorts were determined using FAOICLARM Stock Assessment Tools (FiSAT software, provided in http://www. fao.org/fi/statist/fisoft/fisat/index.htm). For Pomatoschistus minutus and Pomatoschistus microps, as the class interval for the length frequency analyses was lower than $0.25 \mathrm{~cm}$, ANAMOD software package was used, which provided the modes and their standard deviation, and checked the reliability of the estimated parameters. This analysis is described in Dolbeth et al. (2007a).

After recognition of the cohorts, the annual production was estimated by the cohort increment summation method (Winberg, 1971), according to:

$P_{\mathrm{cn}}=\sum_{t=0}^{T-1}\left(\frac{N_{t}+N_{t+1}}{2}\right) \times\left(\bar{w}_{t+1}-\bar{w}_{t}\right)$

where $P_{\mathrm{cn}}$ is the growth production $\left(\mathrm{g} \mathrm{WW} \mathrm{m}^{-2} \mathrm{y}^{-1}\right)$ of cohort $n ; N$ is the density (ind $\mathrm{m}^{-2}$ ); $\bar{w}$ is the mean individual weight (g WW $\mathrm{m}^{-2}$ ); and $t$ and $t+1$, consecutive sampling dates. Population production estimates correspond to the sum of each cohort production $\left(P_{\mathrm{cn}}\right)$. Negative production values were not accounted for the overall fish estimates, which were regarded as no production. Production estimates were also presented with the correction for the catch efficiency of the sampling gear (beam trawl), which according to Hemingway and Elliott (2002) is 30\%.

The mean annual biomass $(\bar{B})$ was estimated according to:

$\bar{B}=\left(\frac{1}{T}\right) \times \sum_{n=1}^{\mathrm{Nc}}\left(\bar{B}_{\mathrm{cn}} t_{\mathrm{cn}}\right)$

where $T$ is the period of study, which is always 365 days (yearly cycles) as the mean annual biomass is being computed; $\mathrm{Nc}$ is the number of cohorts found in the study period; $\bar{B}_{\mathrm{cn}}$ is the mean biomass $\left(\mathrm{g} \mathrm{WW} \mathrm{m}^{-2}\right)$ of cohort $n ; t_{\mathrm{cn}}$ is the time period of the cohort $n$ (days), from the first appearance of individuals until they disappeared.

\section{Results}

\subsection{Environmental background}

From June 2003 to May 2006, precipitation showed unusual variations when compared to the mean precipitation regime for central Portugal observed during the period of 1940-1997 (annual precipitation values of $1030 \mathrm{~mm}$, INAG http://snirh.inag.pt) (Fig. 2A). All years had lower annual precipitation values when compared to the 1940-1997 mean, especially in 2004 and 2005, considered as dry years. The lowest annual precipitation was observed in $2005(486.1 \mathrm{~mm})$, with below-mean precipitation periods quite evident practically during all year (from January until September 2005) extreme drought (Fig. 2A). The freshwater runoff from the Mondego river basin had a severe reduction in 2005, with
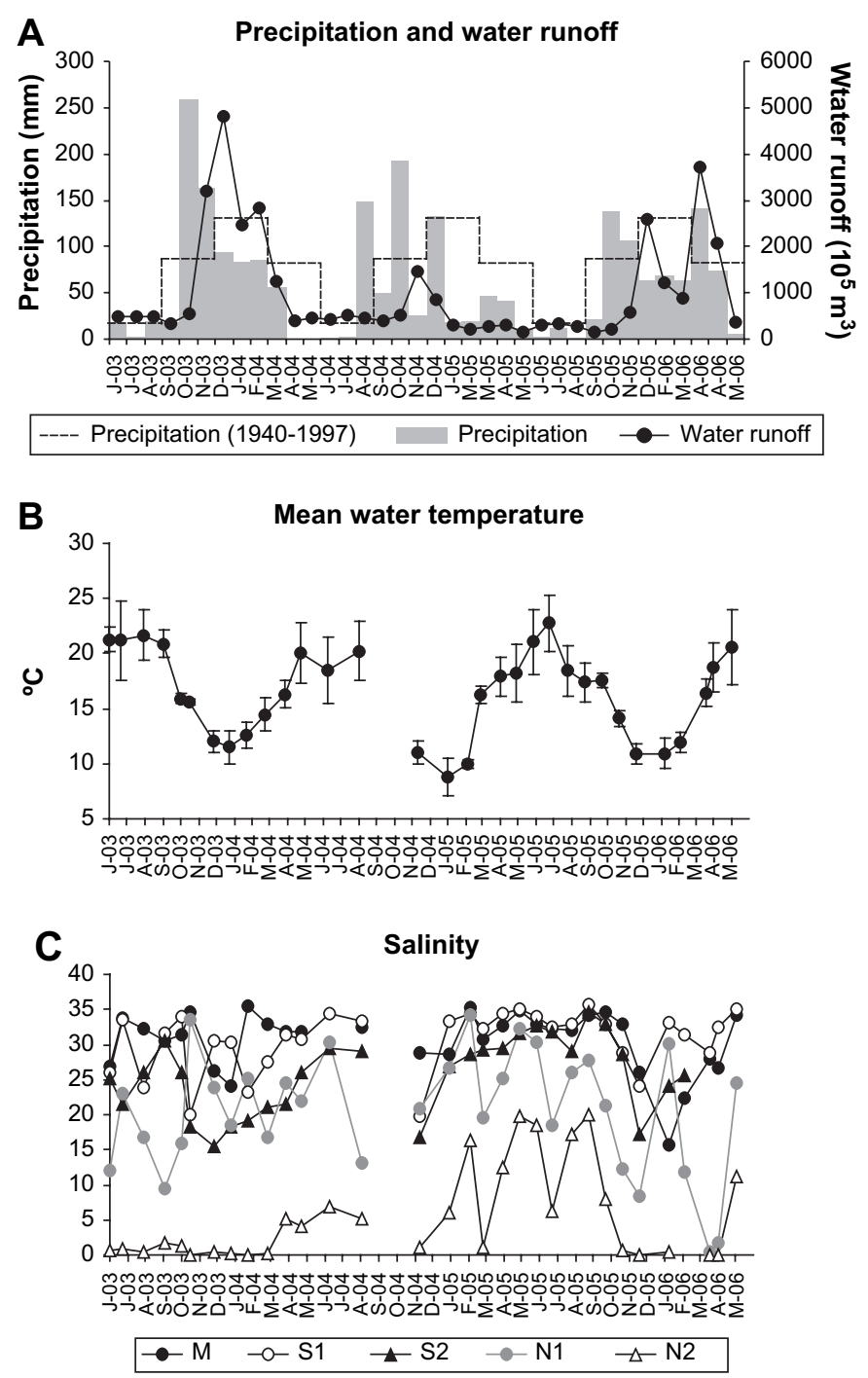

Fig. 2. Temporal variations of: (A) precipitation during the study period and mean precipitation for central Portugal during the period of 1940-1997 and freshwater runoff to the Mondego estuary; (B) mean estuarine water temperature \pm standard deviation for the whole Mondego estuary; and (C) salinity in the different sampling stations of the Mondego estuary. 
values considerably lower (on average $1 / 3$ lower, until October the water runoff was always lower than $350 \times 10^{5} \mathrm{~m}^{3}$ ) than the ones observed in 2003 and 2006 (Fig. 2A). Consequently, salinity was highly variable, with the highest values observed in 2005 (Fig. 2B). Spatially, in the estuary's mouth (station M) salinity presented typical values for marine water, except for the winter 2006 (Fig. 2B). In general, higher salinities were recorded in the south arm (stations S1 and S2) than in the north arm (N1 and N2) (Fig. 2B). Station S1 showed similar values to the ones recorded in the estuary's mouth $(\mathrm{M})$, while stations $\mathrm{S} 2$ and $\mathrm{N} 1$ presented typical brackish water values (Fig. 2B). The most upstream area (station N2) showed the lowest salinities, ranging between 0 and 2 (Fig. 2B). Yet, in 2005, abnormal high salinities were observed (14.0 \pm 6.46 from February 05 to September 05, Fig. 2B), due to low precipitation and low freshwater runoff (extreme drought, Fig. 2A).

Water temperature showed variations usually found in temperate systems, with increasing values in the spring (March-June), until reaching the highest values in the summer (July-September) and lowest values in the winter periods (December-February). In July 2003 and July 2005 higher temperatures were observed when compared to the same period in 2004, with the highest values recorded in the upstream sampling stations $\left(24{ }^{\circ} \mathrm{C}-26{ }^{\circ} \mathrm{C}\right.$ night temperature at S2 and N2) (Fig. 2B).

More information on the environmental and hydrological parameters (e.g. dissolved oxygen, $\mathrm{pH}$, water transparency, chlorophyll a) is reported in Dolbeth et al. (2007a) and Marques et al. (2007).

\subsection{Fish density, biomass and production}

Mean annual density, biomass and production of the community estimates showed a clear decreasing trend along the study period for the fish species in study, with the highest values observed in 2003/04, almost two-fold the values occurring in 2005/06 (Table 1). For each species alone, this tendency was maintained for the mean density values, yet both Platichthys flesus and Solea solea had higher production values in 2004/05 than in the other years (Table 1). Pomatoschistus microps maintained similar values of mean biomass and production throughout the three-year study period (Table 1). Comparing all species, the highest production values, highest mean density and biomass were observed for Dicentrarchus labrax (except for the mean biomass in 2005/06). Solea solea was the second most productive species, with the highest production obtained in 2004/05 (Table 1). The resident species Pomatoschistus minutus and P. microps had the lowest mean biomass values and the lowest production estimates (Table 1). In fact, $P$. microps was the least productive species, although it attained high densities (Table 1). The $P / \bar{B}$ ratios ranged from 1.3 (for P. minutus) to 3.9 (for S. solea), with no clear tendency variation (Table 1). Pomatoschistus microps was the only species that maintained similar $P / \bar{B}$ ratios through the three-year study period (Table 1).

The trend of the annual density, biomass and production values was clarified with the study of their tendencies along the three-year study period (Figs. 3 and 4). The highest production peaks were observed for Dicentrarchus labrax in 2003 (Fig. 4A), together the highest increase in density (Fig. 3A). By the end of 2004 and beginning of 2005 it was observed another peak in production (Fig. 4A), but now associated an increase in biomass (Fig. 3A). During the period of 2005/06, density, biomass and production were lower (Figs. $3 \mathrm{~A}$ and $4 \mathrm{~A})$. For Solea solea the highest peaks in production were observed by the end of 2004 and in 2005 (Fig. 4B) together with the high increases of density and biomass (Fig. 3B). Density was highest in the beginning of 2003, yet

Table 1

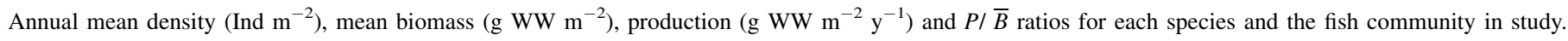
Between brackets production values after correction for the catch efficiency of the beam trawl $(30 \%)$

\begin{tabular}{|c|c|c|c|c|c|c|}
\hline & D. labrax & S. solea & P.flesus & P. minutus & P. microps & All \\
\hline \multicolumn{7}{|c|}{ Density (Ind $\mathrm{m}^{-2}$ ) } \\
\hline $2003 / 04$ & 0.0150 & 0.0024 & 0.0025 & 0.0076 & 0.0088 & 0.036 \\
\hline $2004 / 05$ & 0.0031 & 0.0012 & 0.0017 & 0.0011 & 0.0083 & 0.015 \\
\hline $2005 / 06$ & 0.0029 & 0.0013 & 0.0005 & 0.0017 & 0.0046 & 0.011 \\
\hline \multicolumn{7}{|c|}{ Biomass $\left(\mathrm{g} \mathrm{WW} \mathrm{m}^{-2}\right)$} \\
\hline 2003/04 & 0.10 & 0.07 & 0.05 & 0.005 & 0.0013 & 0.22 \\
\hline $2004 / 05$ & 0.08 & 0.06 & 0.05 & 0.002 & 0.0013 & 0.19 \\
\hline $2005 / 06$ & 0.04 & 0.09 & 0.02 & 0.001 & 0.0010 & 0.15 \\
\hline \multicolumn{7}{|c|}{ Production (g WW $\left.\mathrm{m}^{-2} \mathrm{y}^{-1}\right)$} \\
\hline $2003 / 04$ & $\begin{array}{l}0.44 \\
(1.47)\end{array}$ & $\begin{array}{l}0.19 \\
(0.65)\end{array}$ & $\begin{array}{l}0.11 \\
(0.38)\end{array}$ & $\begin{array}{l}0.017 \\
(0.056)\end{array}$ & $\begin{array}{l}0.0036 \\
(0.012)\end{array}$ & $\begin{array}{l}0.77 \\
(2.57)\end{array}$ \\
\hline $2004 / 05$ & $\begin{array}{l}0.20 \\
(0.67)\end{array}$ & $\begin{array}{l}0.24 \\
(0.78)\end{array}$ & $\begin{array}{l}0.13 \\
(0.42)\end{array}$ & $\begin{array}{l}0.004 \\
(0.012)\end{array}$ & $\begin{array}{l}0.0030 \\
(0.011)\end{array}$ & $\begin{array}{l}0.57 \\
(1.91)\end{array}$ \\
\hline $2005 / 06$ & $\begin{array}{l}0.14 \\
(0.48)\end{array}$ & $\begin{array}{l}0.19 \\
(0.63)\end{array}$ & $\begin{array}{l}0.07 \\
(0.22)\end{array}$ & $\begin{array}{l}0.002 \\
(0.005)\end{array}$ & $\begin{array}{l}0.0030 \\
(0.010)\end{array}$ & $\begin{array}{l}0.39 \\
(1.31)\end{array}$ \\
\hline \multicolumn{7}{|c|}{$P / \bar{B}\left(\mathrm{y}^{-1}\right)$} \\
\hline $2003 / 04$ & 4.3 & 3.0 & 2.3 & 3.3 & 2.7 & 3.5 \\
\hline $2004 / 05$ & 2.5 & 3.9 & 2.8 & 2.1 & 2.4 & 3.1 \\
\hline $2005 / 06$ & 3.2 & 2.1 & 3.6 & 1.3 & 2.9 & 2.6 \\
\hline
\end{tabular}



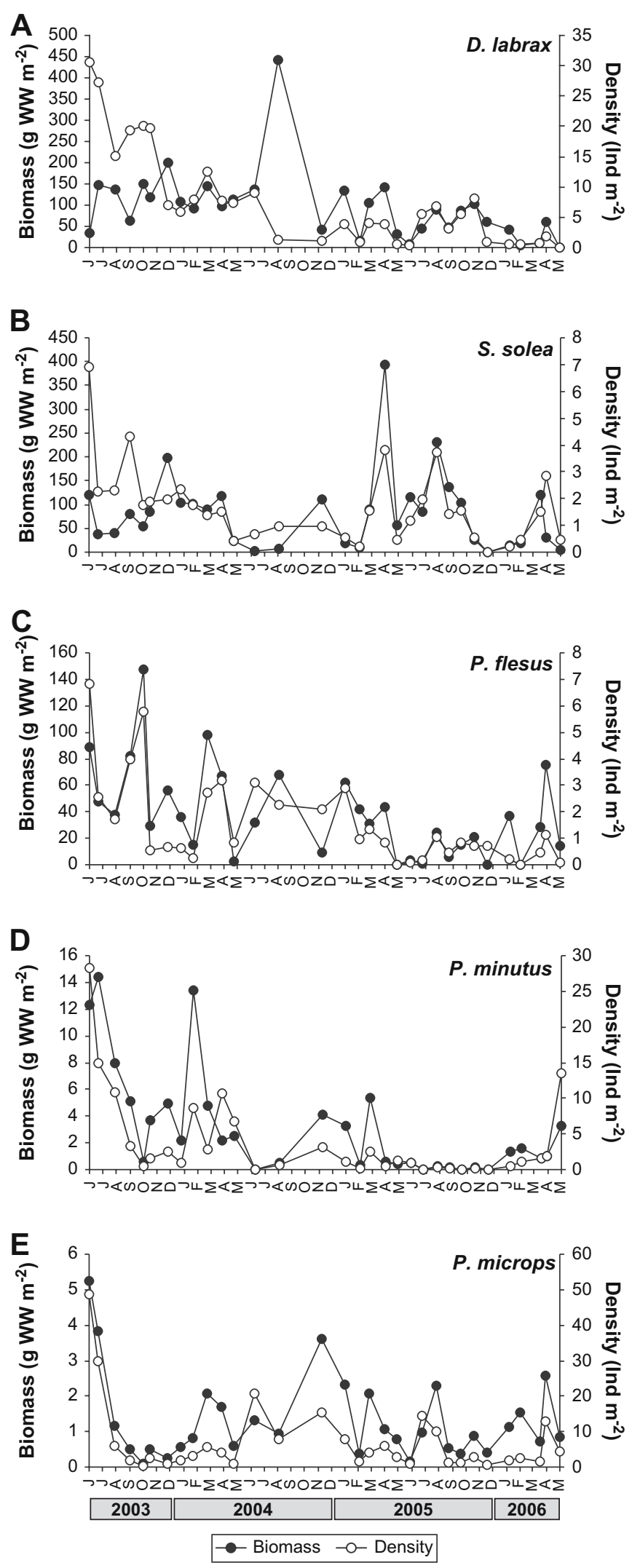

Fig. 3. Monthly variation of mean density and mean biomass along the three-year study period for: (A) Dicentrarchus labrax; (B) Solea solea; (C) Platichthys flesus; (D) Pomatoschistus minutus; and (E) Pomatoschistus microps.
A

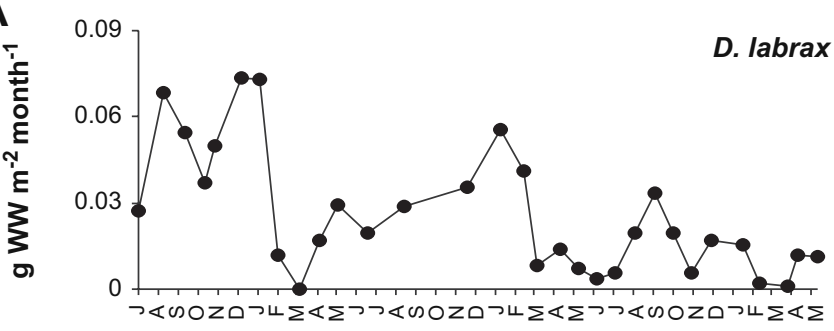

B

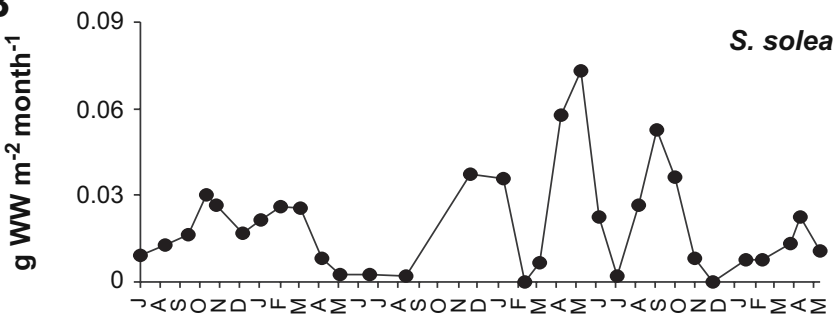

C

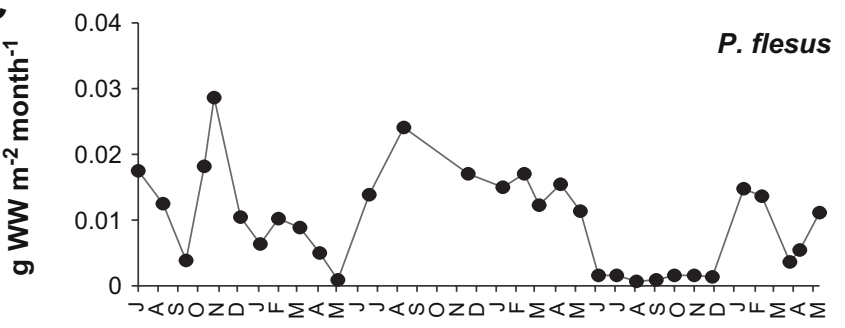

D

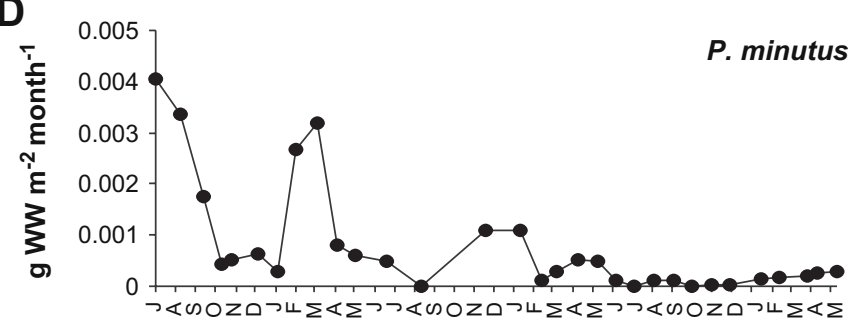

E

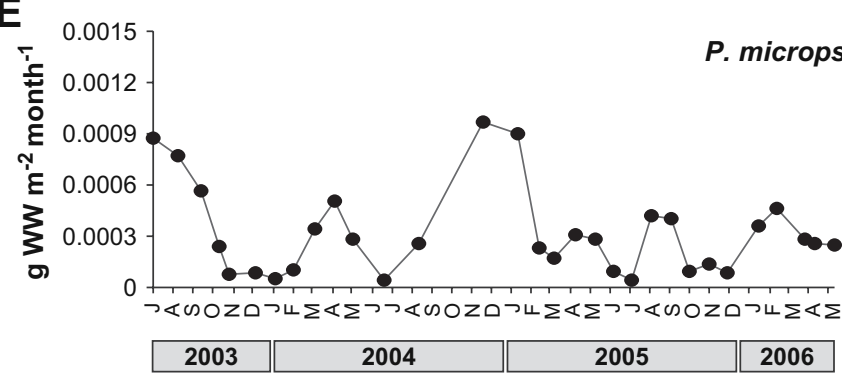

Fig. 4. Monthly variation of production along the three-year study period for: (A) Dicentrarchus labrax; (B) Solea solea; (C) Platichthys flesus; (D) Pomatoschistus minutus; and (E) Pomatoschistus microps.

with lower biomass (Fig. 3B). In 2006, there was a decrease in density, biomass and production (Figs. 3B and 4B). Platichthys flesus was the least productive of the nursery species. Its production maintained similar values throughout the study period, with exception of May 2004 and from June to December 2005, when production decreased considerably (Fig. 4C), altogether 
with the density and biomass decreases (Fig. 3C). The production of the resident species was at least three-fold lower than the nursery species. Density attained similar or higher values than the nursery species, yet the biomass was considerably lower (Fig. 3D,E). Pomatoschistus minutus showed the highest increases of density, biomass and production in 2003/04, decreasing afterwards to considerably lower values from 2005 until the end of the study period (Figs. 3D and 4D). Pomatoschistus microps had the highest density, biomass and production values in 2003 and in the winter of 2004/05 (Figs. 3E and $4 \mathrm{E})$.

\subsection{Recruitment and potential for exportation of nursery fish species}

For Dicentrarchus labrax recruitment occurred systematically in June (Fig. 5A). Individuals stayed in the estuary until at least 18-19 months (see cohorts C2, C3 and C4), disappearing afterwards by the end of January-February, when individuals reached $20-25 \mathrm{~cm}$ in total length (Fig. 5A). After this period, only few larger individuals were found (between 2 and 3 years old, Fig. 5A). Comparing the mean annual production of cohorts $\mathrm{C} 3$ and $\mathrm{C} 4$, the only ones whose complete
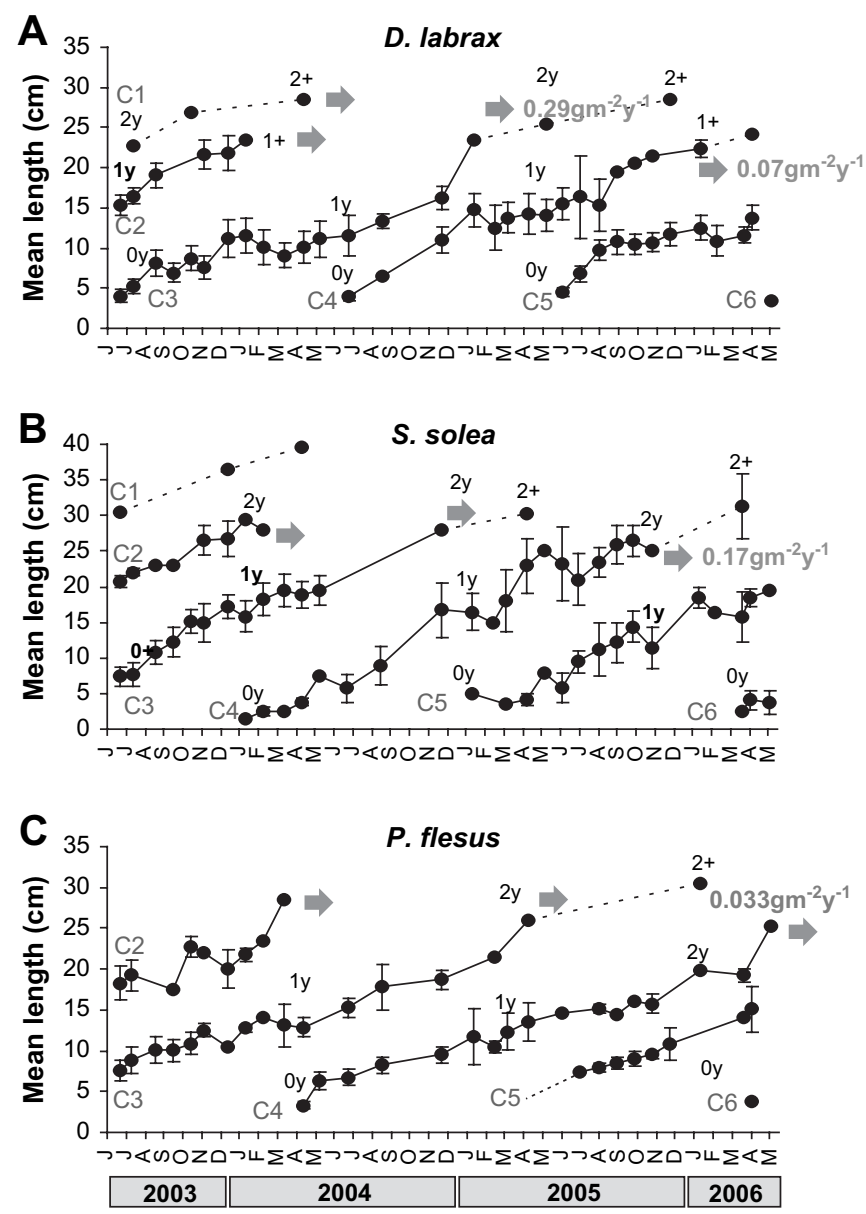

Fig. 5. Linear growth of the nursery species (Dicentrarchus labrax, Solea solea and Platichthysflesus) \pm standard deviation, with indication of production of the seawards migrating individuals for a selected length interval and time period. development in the estuary could be followed, $\mathrm{C} 3$ showed a noticeably higher production than $\mathrm{C} 4$ (Fig. 5A). The lack of a significant part of the other cohorts (only the larger individuals in $\mathrm{C} 2$ and only the juveniles in C5) does not enable to have a comparable measure of their productive potential and exportation (Fig. 5A). Yet, the mean monthly production for the same selected time period and similar length class interval was also estimated (Table 2). With this procedure comparisons could be made regarding the production potential of three consecutive recruitments, based on the youngest individuals (Table 2). For D. labrax, there was a clear decrease over the three-year study period, with the highest production obtained for the recruits of 2003, followed by considerably lower production for the recruits of 2004 and 2005 (Table 2).

For Platichthys flesus and Solea solea the recruitment period was not as constant in time as for Dicentrarchus labrax. Solea solea recruitment seemed to occur in January (Fig. 5B). Yet, in 2006 recruitment was clearly delayed to April (C6), as extremely small size length classes appeared only in April (Fig. 5B). Similarly to the other species, individuals of $S$. solea disappeared the estuary around by November/December, no individuals were caught with more $25 \mathrm{~cm}$ and approximately 20 months (Fig. 5B). Older individuals returned to the estuary occasionally (C3 and C4, Fig. 5B). Only C4 could be followed throughout its complete estuarine lifespan (Fig. 5B). The production of S. solea recruits from 2003 and 2004 was similar and decreased considerably with the recruits of 2005 (Table 2).

Regarding Platichthys flesus, recruitment seemed to occur in April (clear in 2004 and 2006). With the present data, this April recruitment was not evident in 2003 and 2005, as in 2003 there was no data before June, and in 2005 the new cohort only appeared in July (C3 and C5 respectively, Fig. 5C). It is difficult to ascertain if the recruitment of April was delayed to June/July or if no juveniles were caught in April/May 2005. However, individuals caught in July 2003 and 2005 were larger than $6 \mathrm{~cm}$, which was the same length of the July 2004 individuals (Fig. 5C). Platichthys flesus individuals stayed at least two years in the estuary, migrating around April-May (Fig. 5C). Larger individuals showed only occasional occurrence and completely disappeared before

Table 2

Monthly production of the selected lengths and time interval for the three consecutive cohorts of the nursery species (Dicentrarchus labrax, Platichthys flesus and Solea solea)

\begin{tabular}{llllll}
\hline & Cohort & Recruitment & $\begin{array}{l}\text { Length } \\
\text { interval } \\
(\mathrm{cm})\end{array}$ & $\begin{array}{l}\text { Time interval } \\
\text { (months) }\end{array}$ & $\begin{array}{l}\text { Production } \\
\text { per month } \\
\left(\mathrm{g} \mathrm{WW} \mathrm{m}^{-2}\right. \\
\left.\text { month }^{-1}\right)\end{array}$ \\
\hline D. labrax & 3 & 2003 & $4-12$ & 10 & 0.031 \\
& 4 & 2004 & $4-14$ & 10 & 0.007 \\
& 5 & 2005 & $5-14$ & 10 & 0.009 \\
S. solea & 3 & 2003 & $7-20$ & 10 & 0.015 \\
& 4 & 2004 & $6-23$ & 10 & 0.014 \\
& 5 & 2005 & $6-19$ & 10 & 0.006 \\
P. flesus & 3 & 2003 & $8-14$ & 9 & 0.006 \\
& 4 & 2004 & $7-14$ & 9 & 0.005 \\
& 5 & 2005 & $7-14$ & 9 & 0.001 \\
\hline
\end{tabular}


achieving three years (Fig. 5B,C). Only $\mathrm{C} 4$ could be followed throughout its complete estuarine lifespan (Fig. 5B). Similarly to Solea solea, the production of $P$. flesus recruits from 2003 and 2004 was similar, but it decreased considerably with the recruits of 2005 (Table 2).

Comparing the production assessed for the partial cohorts of all species, the highest values were observed for Dicentrarchus labrax recruits of 2003, followed the recruits of Solea solea of 2003 and 2004 (Table 2). The lowest partial cohort production was obtained for Platichthys flesus recruits (Table 2).

\section{Discussion}

\subsection{Fish production general considerations}

Fish populations are very dynamic due to fluctuating levels of recruitment and migration (Costa et al., 2002; Cowley and Whitfield, 2002; Pombo et al., 2007), which bears problems when trying to estimate their production. In estuaries, several fishes have only an occasional occurrence, while others migrate according to age and hydrological environment (Elliott and Dewailly, 1995; Costa et al., 2002), conditioning a correct assessment of their population dynamics. Accurate estimates of fish production are provided with both a short time interval relative to the population dynamics of the fish and with a large population size (Elliott, 2002). Therefore, the present study dealt only with the production estimation for the most abundant fish species of the Mondego estuary. These comprised more than $75 \%$ of the whole fish community density for the studied years (Martinho et al., 2007b) and about 56\% of the community biomass (unpublished data). Estimates were representative of the nursery species production (100\% of density and biomass), and of the resident species production (88\% of density and $63 \%$ of the biomass) potential within the estuary.

Negative production values were not accounted for the production estimates. In fish populations, these negative productions have been associated to possible migration and/or size selective mortality and have been accounted for the production estimates (Costa et al., 2002; Pombo et al., 2007). The studied species are supposed to spend their life cycle (resident) or their early life stages (nursery) in the estuary (Elliott and Dewailly, 1995), therefore the negative values were not considered for the annual production estimates evaluation, as these could lead to an underestimation of the estuarine production.

\subsection{Resident and nursery species production}

In general, the production of the resident and the marine juvenile species of the Mondego estuary seemed lower when compared to other estuarine systems, even after correcting the production estimates for the catch efficiency of the sampling gear (beam trawl) (Table 3). As a result, the expectation that production would increase with decreasing latitudes (Cowley and Whitfield, 2002) did not occur, similarly to the findings of Pombo et al. (2007), though this relationship occurred with the macrozoobenthic intertidal community

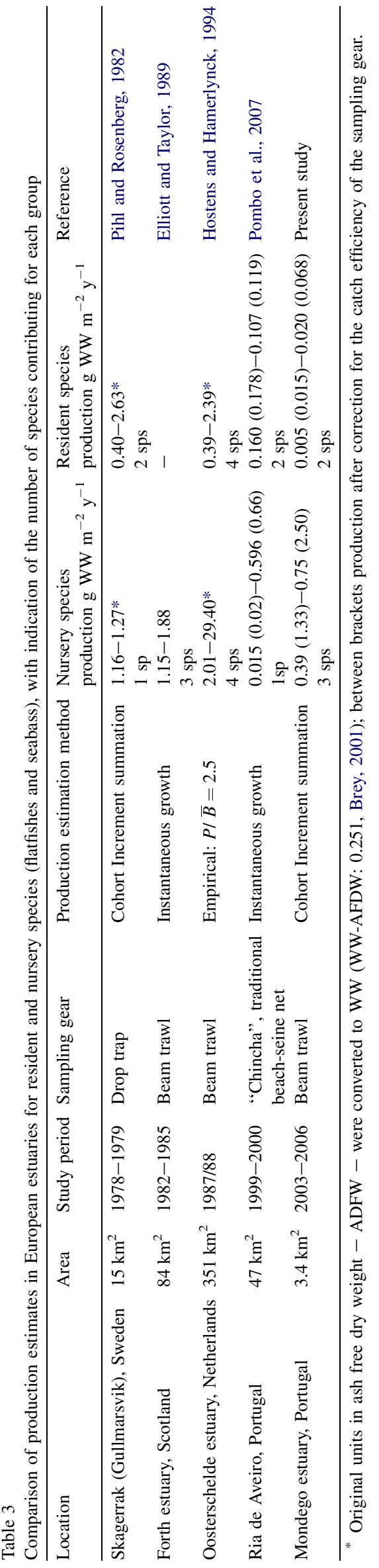


production (Dolbeth et al., 2007b). There are several possible sources of error when assessing the fish production (more detailed information in Costa et al., 2002 and Cowley and Whitfield, 2002), which turns difficult to compare with other estimates elsewhere. Nevertheless, hypotheses related with environmental pressures (discussed later in text) within the estuary or its relatively small area (at least less than $1 / 4$ area than the other studied ecosystems, Table 3) may be suggested. It is also possible that an important part of the fish production was not accounted, as the fish inhabiting the seagrass and saltmarsh areas of the Mondego estuary were not correctly assessed. These are known as important nursery areas, providing both food and shelter for several small fishes (Beck et al., 2001; Costa et al., 2001; Cabral et al., 2007), and where fish production can be considerably higher compared to unvegetated areas (Edgar and Shaw, 1995). Moreover, the relative low density and biomass of the marine species, hence production, may be attributed to the small area compared to other systems, and small opening of the Mondego estuary, which may limit the entrance of marine species (Martinho et al., 2007b). However, in some occasions, the nursery species production of the Mondego overcame the estimates from other estuaries and coastal lagoons (Table 3).

For the Mondego estuary, the annual production of the nursery species was higher than the production of the resident ones, contrarily to Pombo et al. (2007), where Atherina boyeri, a pelagic resident species (not easily caught by the beam trawl used in the present study), had a high production in the estuary. In general, the resident species attained higher densities (especially Pomatoschistus microps in 2004-2006) but these coupled with considerably low biomasses, resulted in lower productions. Among the nursery species, Dicentrarchus labrax was the most productive. Similar production values were obtained in the Ria the Aveiro, also in Portugal (0.02$0.66 \mathrm{~g} \mathrm{WW} \mathrm{m}^{-2} \mathrm{y}^{-1}$, Pombo et al., 2007), yet few data exists on the sea bass production in natural conditions elsewhere for comparative purposes (Costa et al., 2002). The production seemed to decrease after the migration period, hypothesized to occur between January/February, which agrees with downstream dispersion of the older individuals occurring in the winter and early spring (Leitão et al., 2007; Martinho et al., 2007a). For Platichthys flesus, production decreases after the migration period was not so clear. Annual production was lower than the one observed in the Forth estuary (around $1.3 \mathrm{~g} \mathrm{WW} \mathrm{m}^{-2} \mathrm{y}^{-1}$, Elliott and Taylor, 1989) where this species behaves as resident (Elliott and Dewailly, 1995), but similar with other systems elsewhere ( 0.07 for the Elbe and $0.16 \mathrm{~g} \mathrm{WW} \mathrm{m}^{-2} \mathrm{y}^{-1}$ for the Oosterschelde estuaries, Costa et al., 2002). Although it was not concluded a preference of this species for colder waters (within a range of $11-26^{\circ} \mathrm{C}$ ), the north and central coast of Portugal (i.e., Mondego estuary) appears to be the southern limit for the distribution of $P$. flesus (Cabral et al., 2007). Also, the decrease in more southern areas (e.g. Tagus estuary) has been associated to increases in water temperature (Cabral et al., 2001), which also occurred in the Mondego estuary and could explain the lower productions obtained. Solea solea maintained a similar production throughout the study period and similar values to other systems elsewhere $(0.02$ for the Irish Sea, Costa et al., 2002, and $0.24 \mathrm{~g} \mathrm{WW} \mathrm{m}^{-2} \mathrm{y}^{-1}$ for Osterschelde estuary, Hostens and Hamerlynck, 1994). Pomatoschistus minutus showed a considerable decrease in production in the drought year of 2005 contrarily to $P$. microps, which is more tolerant to higher temperatures (Fonds and Buurt, 1974). More details and comparisons of both Pomatoschistus spp. productions can be found in Dolbeth et al. (2007a).

\subsection{Implications of anthropogenic and natural impacts}

Important anthropogenic impacts have been occurring in the Mondego estuary that, to certain extent, might have compromised the fish production. Among anthropogenic impacts affecting the fish community, bank reclamation (due to port activities and agriculture), fishing and eutrophication, with consequent reduction of the seagrass beds (more details in Cardoso et al., 2005; Dolbeth et al., 2007b), were considered as major impact sources (Martinho et al., 2007b; Vasconcelos et al., 2007). Although there are no fish production estimates from the past, it is quite plausible that the production might have decreased, both due to a decrease of alternative habitats (Leitão et al., 2007; Martinho et al., 2007a; Vasconcelos et al., 2007) and due to the overall decrease in the macrobenthic production (Dolbeth et al., 2007b). The decrease in the macrobenthic production means a decrease in food availability, as the studied species feed intensively on the macrobenthos (Leitão et al., 2006; Martinho et al., in press). Also, trends of the fish community over the last two decades showed lower fish diversity at the present time (Leitão et al., 2007).

Estuaries are exposed to severe of anthropogenic and inherent natural stress, being difficult to distinguish between the two sources of impacts (Elliott and Quintino, 2007). The fish community composition, as well as the population dynamics of single species, seems to be strongly affected by density independent factors, such as temperature, salinity, wind regime, tides (among others) in several estuarine systems (Marshall and Elliott, 1998; Powers et al., 2000; Costa et al., 2002; Maes et al., 2004; Akin et al., 2005). Regarding climate variability impacts on the Mondego estuary within the study period, the gradual occurrence of a drought (starting by a normal hydrological year in 2003 and attaining a severe drought in 2005), high water temperatures and low freshwater discharges seemed the most relevant episodes. Accordingly, the production showed a clear decrease during the dry year of 2005, with the highest decreases observed for Dicentrarchus labrax, Platichthys flesus and Pomatoschistus minutus. It is difficult to ascertain the main factors for this decrease (in agreement to the "Estuarine Quality Paradox", Elliott and Quintino, 2007), yet experimental studies have revealed the limiting effect of high temperatures and salinity variations on eggs and larval development of P. minutus and Pomatoschistus microps (Fonds and Buurt, 1974) and of P. flesus (Cabral et al., 2007). Solea solea seems more tolerant to variations in temperature and salinity (Fonds, 1975). Some studies have also showed a positive influence of moderate river discharges 
for an overall increase in primary production of estuarine systems (Houde and Rutherford, 1993; Costa et al., 2002, 2007; Vinagre et al., 2007), with consequent impacts on the production of the other trophic levels. Additionally, river drainage has been positively associated with marine juvenile densities, due to the existence of chemical cues used by their larvae for movement orientation into the estuary (Costa et al., 2007; Vinagre et al., 2007). Drought and the consequent decrease in river discharge will lower both the primary production and the chemical cues reaching coastal waters, less detectable by larvae. These relationships between fish abundance and freshwater flow may be quite different according to species (Costa et al., 2007), and several studies have showed an increase in the fish community density in dry years (Costa et al., 2007). Yet, others showed that the recruitment of the marine species could be reduced (Costa et al., 2002), as well as the overall density of the resident species (Martinho et al., 2007b). Altogether, these studies highlight the hypothesis that salinity, temperature and river discharge variations may be major driving forces acting in the recruitment success and population development of the studied species, due to high natural mortality. This change in the environmental conditions might have increased the predation pressure by piscivorous fishes (mostly marine adventitious species) whose abundance increased in the estuary (Martinho et al., 2007b), or induced seawards migration, as also suggested by Dolbeth et al. (2007a) for the resident species. Additionally, for the marine spawning fishes, it is also important to consider other unmeasured aspects that might have influenced the recruitment, such as reproductive success on continental shelf related with the oceanographic conditions (Vinagre et al., 2007).

Ultimately, the decrease in the fish production may have important consequences for the adult stocks of the marine species (see below) and for the estuarine food web, as the resident species are dominant prey of several other fishes (Dolbeth et al., 2007a).

\subsection{Exportation of commercially important fish species}

Estuaries are crucial for the overall development of several fish populations and what happens in the estuarine system may compromise the coastal stocks and ultimately the fisheries, with important socio-economic impacts (Houde and Rutherford, 1993). Several marine spawning fishes have an estuarine residence phase during the early life cycle and then an emigration back to the coastal areas (Cabral et al., 2007; Martinho et al., 2007a). This emigration will transfer large amounts of energy, which was accumulated in the estuary (Cowley and Whitfield, 2002; Gillanders et al., 2003). In fact, in several locations, a fraction higher than $50 \%$ of the fisheries harvests is estuarine or estuarine-dependent in at least some life stages (Houde and Rutherford, 1993; Able, 2005). In the present study, a direct measurement and comparison of each recruitment production contribution to exportation was not possible, as not all the cohorts could be followed completely. It is also difficult to evaluate the actual connectivity of this estuarine production to the coastal area (Gillanders et al., 2003; Able,
2005; Gillanders, 2005). Nevertheless, at least part of the cohort from consecutive recruitments, occurring in different hydrological years (i.e., with gradual drought effect) could be assessed and their consequent potential production for exportation evaluated and compared. For Platichthys flesus and Solea solea the lowest production was observed when the recruitment occurred in 2005, the extreme dry year. For Dicentrarchus labrax a clear reduction in production was also observed in 2005 , but the lowest value was obtained in 2004, also a dry year. Such reduction in production (and potential reduction of emigrating fish) could influence the biodiversity and stability of the neighbouring inshore coastal or shelf ecosystems (Cowley and Whitfield, 2002). Ultimately, this could affect the economy, due to the high commercial value of the studied species.

\section{Acknowledgements}

The authors are indebted to Daniel Crespo, Heliana Teixeira, João Miguel Neto, Ricardo Leitão and Tiago Verdelhos who helped in field work. This work was supported by the FCT (Portuguese Foundation for Science and Technology) through a $\mathrm{PhD}$ grant attributed to $\mathrm{M}$. Dolbeth (SFRH/BD/ 14112/2003).

\section{References}

Able, K.W., 2005. A re-examination of fish estuarine dependence: evidence for connectivity between estuarine and ocean habitats. Estuarine, Coastal and Shelf Science 64, 5-17.

Akin, S., Buhan, E., Winemiller, K.O., Yilmaz, H., 2005. Fish assemblage structure of Koycegiz Lagoon Estuary, Turkey: spatial and temporal distribution patterns in relation to environmental variation. Estuarine, Coastal and Shelf Science 64, 671-684.

Beck, M.W., Heck, K.L., Able Jr., K.W., Childers, D.L., Eggleston, D.B., Gillanders, B.M., Halpern, B., Hays, C.G., Hoshino, K., Minello, T.J., Orth, R.J., Sheridan, P.F., Weinstein, M.P., 2001. The identification, conservation, and management of estuarine and marine nurseries for fish and invertebrates. Bioscience 51, 633-641.

Brey, T., 2001. Population dynamics in benthic invertebrates. A virtual handbook. Version 01.2. Alfred Wegener Institute for Polar and Marine Research, Germany. http://www.awi-bremerhaven.de/Benthic/Ecosystem/ FoodWeb/Handbook/main.html.

Cabral, H.N., Costa, M.J., Salgado, J.P., 2001. Does the Tagus fish community reflect environmental changes? Climate Research 18, 119-126.

Cabral, N.H., Vasconcelos, R.P., Vinagre, C., França, S., Fonseca, V., Maia, A., Reis-Santos, P., Lopes, M., Ruano, M., Campos, J., Freitas, V., Santos, P., Costa, M.J., 2007. Relative importance of estuarine flatfish nurseries along the Portuguese coast. Journal of Sea Research 57, 209-217.

Cardoso, P.G., Brandão, A., Pardal, M.A., Raffaelli, D., Marques, J.C., 2005. Resilience of Hydrobia ulvae populations to anthropogenic and natural disturbances. Marine Ecology Progress Series 289, 191-199.

Costa, M.J., Catarino, F., Bettencourt, A., 2001. The role of salt marshes in the Mira estuary (Portugal). Wetlands Ecology and Management 9, 121-134.

Costa, M.J., Cabral, H.N., Drake, P., Economou, A.N., Fernandez-Delgado, C., Gordo, L., Marchand, J., Thiel, R., 2002. Recruitment and production of commercial species in estuaries. In: Elliot, M., Hemingway, K. (Eds.), Fishes in Estuaries. Blackwell Science, United Kingdom, pp. 54-123.

Costa, M.J., Vasconcelos, R., Costa, J.L., Cabral, H.N., 2007. River flow influence on the fish community of the Tagus estuary (Portugal). Hydrobiologia 587, 113-123. 
Cowley, P.D., Whitfield, A.K., 2002. Biomass and production estimates of a fish community in a small South African estuary. Journal of Fish Biology $61,74-89$.

Cusson, M., Bourget, E., 2005. Global patterns of macroinvertebrate production in marine benthic habitats. Marine Ecology Progress Series 297, 1-14.

Dolbeth, M., Lillebø, A.I., Cardoso, P.G., Ferreira, S.M., Pardal, M.A., 2005. Annual production of estuarine fauna in different environmental conditions: an evaluation of the estimation methods. Journal Experimental Marine Biology and Ecology 326, 115-127.

Dolbeth, M., Martinho, F., Leitão, R., Cabral, H., Pardal, M.A., 2007 a. Strategies of Pomatoschistus minutus and Pomatoschistus microps to cope with environmental instability. Estuarine, Coastal and Shelf Science 74, 263-273.

Dolbeth, M., Cardoso, P.G., Ferreira, S.M., Verdelhos, T., Raffaelli, D., Pardal, M.A., 2007b. Anthropogenic and natural disturbance effects on a macrobenthic estuarine community over a 10 -year period. Marine Pollution Bulletin 54, 576-585.

Edgar, G.J., Shaw, C., 1995. The production and trophic ecology of shallowwater fish assemblages in southern Australia I. Species richness, sizestructure and production of fishes in Western Port, Victoria. Journal of Experimental Marine Biology and Ecology 194, 53-81.

Elliott, M., 2002. An overview of the status, study and management of fishes in estuaries. In: Elliot, M., Hemingway, K. (Eds.), Fishes in Estuaries. Blackwell Science, United Kingdom, pp. 556-575.

Elliott, M., Dewailly, F., 1995. The structure and components of European estuarine fish assemblages. Netherlands Journal of Aquatic Ecology 29, 397-417.

Elliott, M., Quintino, V., 2007. The Estuarine Quality Paradox, Environmental Homeostasis and the difficulty of detecting anthropogenic stress in naturally stressed areas. Marine Pollution Bulletin 54, 640-645.

Elliott, M., Taylor, C.J.L., 1989. The Structure and Functioning of an Estuarine/Marine Fish Community in the Forth Estuary, Scotland. In: Proceedings of the 21st. European Marine Biology Symposium. Polish Academy of Sciences and Institute of Oceanology Gdansk, Gdansk, pp. 227-240.

Fonds, M., 1975. The Influence of Temperature and Salinity on the Growth of Young Sole Solea solea L. In: 10th European Symposium on marine Biology, Ostend, Belgium, pp. 17-23.

Fonds, M., Buurt, V.G., 1974. The influence of temperate and salinity on development and survival of goby eggs (Pisces, Gobiidae). Hydrobiological Bulletin 8, 110-116.

Gamito, S., Erzini, K., 2005. Trophic food web and ecosystem attributes of a water reservoir of the Ria Formosa (south Portugal). Ecological Modelling 181, 509-520.

Gillanders, B.M., 2005. Using elemental chemistry of fish otoliths to determine connectivity between estuarine and coastal habitats. Estuarine, Coastal and Shelf Science 64, 47-57.

Gillanders, B.M., Able, K.W., Brown, J.A., Eggleston, D.B., Sheridan, P.F., 2003. Evidence of connectivity between juvenile and adult habitats for mobile marine fauna: an important component of nurseries. Marine Ecology Progress Series 247, 281-295.

Hemingway, K.L., Elliott, M., 2002. Field methods. In: Elliot, M., Hemingway, K. (Eds.), Fishes in Estuaries. Blackwell Science, United Kingdom, pp. 410-509.

Hostens, K., Hamerlynck, O., 1994. The motile epifauna of the soft bottoms in the subtidal Oosterschelde estuary: structure, function and impact of storm-surge barrier. Hydrobiologia 282/283, 479-496.

Houde, E.D., Rutherford, E.S., 1993. Recent trends in estuarine fisheries: prediction of fish production and yield. Estuaries 16, 161-176.

Leitão, R., Martinho, F., Neto, J.M., Cabral, H., Marques, J.C., Pardal, M.A., 2006. Feeding ecology, population structure and distribution of Pomatoschistus microps (Krøyer, 1838) and Pomatoschistus minutus (Pallas,
1770) in a temperate estuary, Portugal. Estuarine, Coastal and Shelf Science 66, 231-239.

Leitão, R., Martinho, F., Cabral, H.N., Neto, J.M., Jorge, I., Pardal, M.A., 2007. The fish assemblage of the Mondego estuary: composition, structure and trends over the past two decades. Hydrobiologia 587, 269-279.

Lilleb $\varnothing$, A.I., Neto, J.M., Martins, I., Verdelhos, T., Leston, S., Cardoso, P.G., Ferreira, S.M., Marques, J.C., Pardal, M.A., 2005. Management of a shallow temperate estuary to control eutrophication: the effect of hydrodynamics on the system's nutrient loading. Estuarine, Coastal and Shelf Science 65, 697-707.

Maes, J., Van Damme, S., Meire, P., Ollevier, F., 2004. Statistical modelling of seasonal and environmental influences on the population dynamics of an estuarine fish community. Marine Biology 145, 1033-1042.

Marques, S.C., Martinho, F., Azeiteiro, U.M., Pardal, M.A., 2007. Climate variability and planktonic communities: The effect of an extreme event (severe drought) in a southern European estuary. Estuarine, Coastal and Shelf Science 73, 725-734.

Marshall, S., Elliott, M., 1998. Environmental Influences on the Fish Assemblage of the Humber Estuary, U.K. Estuarine, Coastal and Shelf Science 46, 175-184.

Martinho, F., Leitão, R., Neto, J., Cabral, H.N., Marques, J.C., Pardal, M.A., 2007a. The use of nursery areas by juvenile fish in a temperate estuary. Portugal. Hydrobiologia 587, 281-290.

Martinho, F., Leitão, R., Viegas, I., Dolbeth, M., Neto, J., Cabral, H.N., Pardal, M.A., 2007b. The influence of an extreme drought event in the fish community of a southern Europe temperate estuary. Estuarine, Coastal and Shelf Science 75, 537-546.

Martinho, F., Leitão, R., Neto, J.M., Cabral, H., Lagardère, F., Pardal, M.A. Estuarine colonization, population structure and nursery functioning for 0-group sea bass (Dicentrarchus labrax), flounder (Platichthys flesus) and sole (Solea solea) in a mesotidal temperate estuary. Journal of Apllied Ichthyology, in press.

Nicolas, D., Le Loc'h, F., Désaunay, Y., Hamon, D., Blanchet, A., Le Pape, O., 2007. Relationships between benthic macrofauna and habitat suitability for juvenile common sole (Solea solea, L.) in the Vilaine estuary (Bay of Biscay, France) nursery ground. Estuarine, Coastal and Shelf Science 73, 639-650.

Patrício, J., Marques, J.C., 2006. Mass balanced models of the food web in three areas along a gradient of eutrophication symptoms in the south arm of the Mondego estuary (Portugal). Ecological Modelling 197, 21-34.

Pihl, L., Rosenberg, R., 1982. Production, abundance and biomass of motile epibenthic marine fauna in shallow waters western Sweden. Journal of Experimental Marine Biology and Ecology 57, 273-301.

Pombo, L., Rebelo, J.E., Elliott, M., 2007. The structure, diversity and somatic production of the fish community in an estuarine coastal lagoon, Ria de Aveiro (Portugal). Hydrobiologia 587, 253-268.

Powers, M., Attrill, M.J., Thomas, R.M., 2000. Environmental factors and interactions affecting the temporal abundance of juvenile flatfish in the Thames Estuary. Journal of Sea Research 43, 135-149.

Vasconcelos, R.P., Reis-Santos, P., Fonseca, V., Maia, A., Ruano, M., França, S., Vinagre, C., Costa, M.J., Cabral, H., 2007. Assessing anthropogenic pressures on estuarine fish nurseries along the Portuguese coast: a multi-metric index and conceptual approach. Science of the Total Environment 374, 199-215.

Vinagre, C., Costa, M.J., Cabral, H.N., 2007. Impact of climate and hydrodynamics on sole larval immigration towards the Tagus estuary, Portugal. Estuarine, Coastal and Shelf Science. doi:10.1016/j.ecss.2007.05.035.

Wilson, J.G., 2002. Productivity, fisheries and aquaculture in temperate estuaries. Estuarine, Coastal and Shelf Science 55, 953-967.

Winberg, G.G., 1971. Methods for the Estimating of Production of Aquatic Animals. Academic Press Inc, London, 175 pp. 